\title{
Analisis Post to Subscriber Ratio Youtube Pada 5 Youtuber Dengan Subscriber Terbanyak Di Indonesia
}

\author{
Lalu Ariawan Ganda Putra \\ laluartawan99@gmail.com
}

\begin{abstract}
ABSTRAK
Youtube merupakan salah satu adalah salah satu wadah yang ada di media sosial yang sangat digemari. Khususnya di Indonesia, jika dibandingkan dengan berbagai macam media sosial yang lain. Pembuat konten youtube yang dikenal dengan sebutan youtuber ini berlomba-lomba mendapatkan penonton (viewers) dan pengikut (subscriber). Seperti 5 Youtuber Dengan Subscriber Terbanyak Di Indonesia, diantaranya yaitu: Atta Halilintar, Ria Ricis, Rafi Ahmad, Baim Paula, dan Deddy CorbuzierPenelitian ini menggunakan metode Eksploratif Kuantitatif, dan akan menghitung dengan ratio-ratio yang ada pada youtube.Hasil dari penelitian ini menunjukan bahwa youtuber Atta Halilintar mendapatkan peringkat pertama dan memiliki kredibilitas performa akun yang baik.Tujuan penelitian ini adalah mengetahui kredibilitas performa pada akun youtube dengan menggunakan Post To Subscriber Ratio pada 5 Youtuber Dengan Subscriber Terbanyak Di Indonesia.
\end{abstract}

\begin{abstract}
Youtube is one of the most popular platforms for social media favored. Especially in Indonesia, when compared to other types of social media. These YouTube content creators, known as YouTubers, are competing to get viewers (viewers) and followers (subscribers). Like the 5 Youtubers with the Most Subscribers in Indonesia, including: Atta Halilintar, Ria Ricis, Rafi Ahmad, Baim Paula, and Deddy Corbuzier. This research uses the Quantitative Exploratory method, and will calculate the ratios on YouTube. The results of this study show that youtuber Atta Halilintar gets the first rank and has good account performance credibility. The purpose of this study is to determine the credibility of the performance on the youtube account by using the Post To Subscriber Ratio on the 5 Youtubers with the Most Subscribers in Indonesia.
\end{abstract}

Keyword : Credibility Account Youtube ; Social Media Youtube ; Analysis Post to Subscriber Ratio; Youtube Indonesia.

\section{PENDAHULUAN}

Teknologi informasi dan komunikasi yang telah berkembang pesat mampu menghantarkan manusia untuk menciptakan bentuk baru cara berkomunikasi dan berinteraksi melalui media sosial. Informasi merupakan kumpulan data yang saling terkait dan telah diproses secara kompleks. Data-data yang tercatat dan saling terkait dikumpulkan, diolah atau diproses sehingga menghasilkan informasi yang tepat dan akurat. Komunikasi merupakan suatu proses penyampaian informasi berupa pesan, ide atau gagasan dari satu pihak kepada pihak lain agar saling mempengaruhi di antara keduanya. Teknologi komunikasi dan informasi merupakan aplikasi pengetahuan dan keterampilan yang digunakan manusia dalam mengalirkan informasi 
atau pesan dengan tujuan untuk membantu menyelesaikan permasalahan manusia agar tercapai tujuan komunikasi.(Hendika Permana 2021)

YouTube merupakan salah satu sosial media yang biasanya digunakan sebagai hiburan untuk memanjakan telinga dan mata kita dengan berbagai macam video yang telah terupload didalamnya. Meskipun memiliki sistem yang hampir mirip dengan televisi, namun perbedaannya adalah televisi memiliki kanal yang terbatas dibandingkan dengan Youtube yang menyediakan berbagai macam video yang bisa dipilih sesuai dengan yang diinginkan. Selain itu nilai tambah untuk YouTube adalah ada terdapat fitur user generated content yang membuat setiap pengguna dapat mengunggah video kreasi yang mereka buat sendiri. Youtuber memiliki pengertian lain yaitu sekelompok atau individu yang memiliki channel YouTube sendiri, membuat, menanyangkan, dan mencari subscribers. Pada awalnya profesi ini hanyalah diawali sebagai hobi saja, namun seiring dengan banyaknya pengunjung platform tersebut menjadikannya sebagai peluang untuk mendapatkan penghasilan jika di seriusi lebih jauh.("Pengertian Youtuber_Profesi, Gaji, Cara Kerja, Tips Viewers Dan Subscriber Tinggi Adam Muiz," n.d.)

YouTuber kini sudah menjadi profesi baru yang amat diminati masyarakat Indonesia. Terlebih jika memiliki subscriber yang banyak, tentu akan meningkatkan channel dan juga penghasilan. Tak sedikit orang yang memutuskan untuk menjadi YouTuber dan memiliki channel YouTube sendiri. Bahkan beberapa konten kreator YouTube asal Indonesia memiliki jumlah subscriber hingga jutaan yang tentunya akan memberikan pendapatan yang banyak pula. Seperti 5 Youtuber Dengan Subscriber Terbanyak Di Indonesia, diantaranya yaitu: Atta Halilintar, Ria Ricis, Rafi Ahmad, Baim Paula, dan Deddy Corbuzier.("Ini-5-Youtuber-Dengan-SubscriberTerbanyak-Raffi-Ahmad-Dan-Nagita-Slavina-Nomor-3-K520qT," n.d.)

Penelitian ini menggunakan metode Eksploratif Kuantitatif, dan akan menghitung dengan ratio-ratio yang ada pada youtube. Pada penelitian (Hendika Permana 2021) menjelaskan tentang youtube memiliki 10 ratio yang digunakan untuk mengukur kredibilitas akun yang ada. Pada penelitian ini hanya berfokus pada menghitung kredibilitas Post To Subscriber Ratio pada 5 Youtuber dengan Subscriber terbanyak di Indonesia. Tujuan penelitian ini adalah mengetahui kredibilitas performa pada akun youtube dengan menggunakan Post To Subscriber Ratio pada 5 Youtuber Dengan Subscriber Terbanyak Di Indonesia.

\section{TINJAUAN PUSTAKA}

Perkembangan teknologi komunikasi saat ini semakin menuju puncaknya. Berbagai bentuk media muncul dan berkembang dengan istilah new media hal ini sangat berpengaruh pada pengguna media tersebut, terutama seperti media youtobe yang menjadi salah satu media sosial yang digunakan sebagai alat berbagi video dengan berbagai konten di dalamnya. Youtube saat ini semakin menjadi fenomena tersendiri bagi kalangan muda khususnya apalagi dengan hak akses yang didapatkan secara gratis. (Sulaeman, A. R., Fazri, A., \& Fairus 2020).

Youtube adalah salah satu media sosial yang memiliki pasar cukup besar saat ini. Dibalik suksesnya media sosial youtube, ada 3 pendiri yang berhasil mengembangkan media sosial ini yaitu, Steve Chen, Chad Hurley dan Jawed Karim, yang sebelumnya mereka merupakan karyawan pertama dari perusahaan PayPal. Youtube merupakan salah satu adalah salah satu wadah yang ada di media sosial yang sangat digemari. Khususnya di Indonesia, jika dibandingkan dengan berbagai macam media sosial yang lain. Pembuat konten youtube yang 
dikenal dengan sebutan youtuber ini berlomba-lomba mendapatkan penonton (viewers) dan pengikut (subscriber). Hal ini juga dikarenakan ada keuntungan secara materi yang didapat oleh akun-akun youtube tersebut jika penonton dan pengikut mereka banyak dan aktif. (Hadi S, Kurniawan, and Irwansyah 2021)

Kini Youtube menjadi media yang paling popular untuk mengunduh atau mengunggah video. Para pengguna dapat memuat, menonton dan berbagi video klip secara gratis. Umumnya video di Youtube adalah klip musik, narasi kegiatan akademik, laporan peristiwa, berita, film, TV, serta video buatan para penggunanya sendiri.(Fadhal and Nurhajati 2012). Dikutip dari web kompas.com, sejumlah public figure atau artis yang biasa kita lihat di televisi kini dapat atau sering kita jumpai dalam layar ponsel atau layar laptop melalui kontennya di platform YouTube, Jumlah subscriber mereka pun beragam. Yang pasti sekali mengunggah video bisa ditonton hingga jutaan kali.

Kredibilitas atau kualitas suatu akun youtuber tentu sangat berpengaruh terhadap konten yang akan disampaikan kepada public. Menurut (Hendika Permana 2021) Kredibilitas dibentuk ketika seseorang yang mengelola akun YouTube tersebut memiliki sumber pengetahuan yang cukup, keterampilan, dan kepercayaan diri sehingga menghasilkan sebuah konten yang memiliki performa yang baik. Kredibilitas sebuah akun dapat diukur dari performa akun yang harus diukur secara sistematis. Dalam mengukur performa dari sebuah akun diperlukan skala pengukuran yang akan tertuang kedalam rasio-rasio. Ada berbagai macam skala pengukuran, diantaranya yaitu : skala nominal, skala ordinal, skala interval, dan skala rasio. Skala pengukuran tersebut yang akan menimbulkan data berupa rasio. Akun YouTube yang dapat dianalisis untuk menentukan kredibilitas, harus memenuhi syarat setting pada pengaturan akun YouTube. Persyaratan tersebut diantaranya yaitu, akun YouTube merupakan akun yang bersifat publik, video yang diposting tidak dikunci (privacy), kolom komentar tidak di nonaktifkan (disable)

\section{METODE PENELITIAN}

Penelitian ini menggunakan metode eksploratif kuantitatif untuk mengetahui kredibilitas dari akun 5 Youtuber dengan subscriber terbanyak di indonesia dengan rasio yang dihasilkan. Penelitian kualitatif disebut juga naturalistic inquiry memandangrealitas sosial bersifat unik antara satu dengan lainnya sehingga sulit untuk melakukan generalisasi tentang keseluruhan kalau hanya didasarkan sebagian. Oleh karena itu pemahaman keseluruhan diperlukan pendekatan holistik. Penelitian eksploratif merupakan sarana yang efektif untuk memberikan gambaran keadaan sosial tertentu. (Firman 2018)

Penelitian ini menggunakan variabel-variabel yang terdapat pada akun sosial media YouTube sebagai objek penelitian sehingga mampu menghasilkan rasio yang relevan. Variabel yang digunakan dalam sebuah penelitian pada dasarnya adalah sesuatu hal yang dapat berbentuk apa saja yang ditetapkan oleh peneliti untuk dipelajari sehingga diperoleh informasi tentang hal tersebut dan kemudian ditarik kesimpulannya.(Liana 2009) Setiap akun youtube memiliki tampilan halaman yang menunjukan profil serta postingan video yang di upload. Pada tampilan akun terdapat variabel seperti jumlah subscriber dan jumlah postingan, sedangkan pada tampilan halaman video yang di posting terdapat variabel jumlah viewers, like, dislike dan comment dari postingan video itu sendiri. Dimana variabel-variabel yang terdapat pada YouTube tersebut yang nantinya akan dibandingkan dan diuji relevansinya sehingga 
menemukan sebuah rasio yang relevan. Berikut merupakan langkah-langkah menemukan variabel pada akun media social youtube.

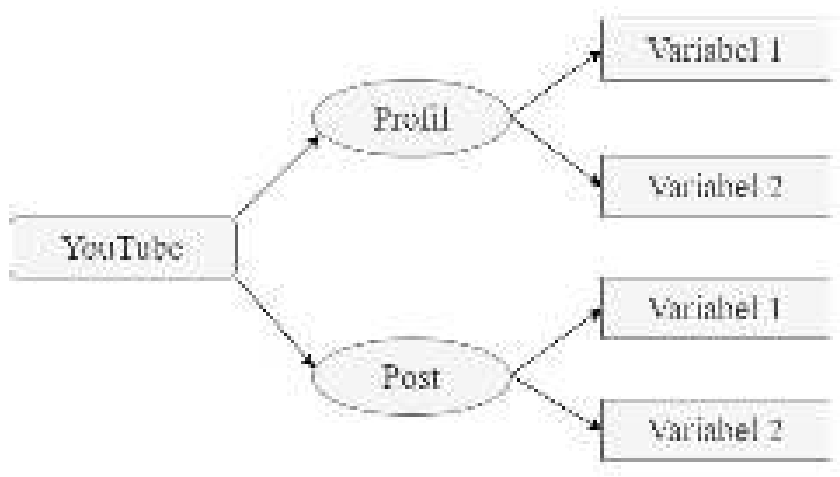

Gambar 1. Menemukan Variabel Akun Youtube.

Langkah-langkah yang dilakukan pada penelitian tipe eksploratif ini yaitu, dalam menentukan sebuah rasio dibutuhkan minimal 2 variabel yang dibandingkan sehingga menghasilkan sebuah nilai yang hasil akhirnya dinyatakan dalam sebuah persentase. Dari seluruh variabel yang ditentukan akan dibandingkan dengan seluruh variabel yang ditemukan lalu diuji relevansinya sehingga dapat ditentukan apakah perbandingan antara kedua variabel dapat dikategorikan sebagai rasio.

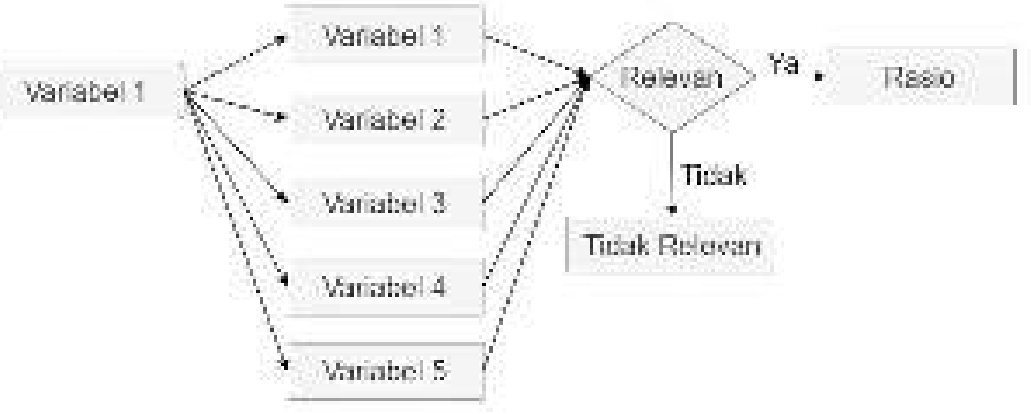

Gambar 2. Relevansi Variabel Terhadap Rasio

Setelah variabel satu selesai di analisa, dilanjutkan dengan variabel kedua, variabel ketiga dan variabel-variabel yang lainnya. Berikut merupakan contoh studi kasus perbandingan antara variabel yang terdapat pada akun sosial media YouTube : 


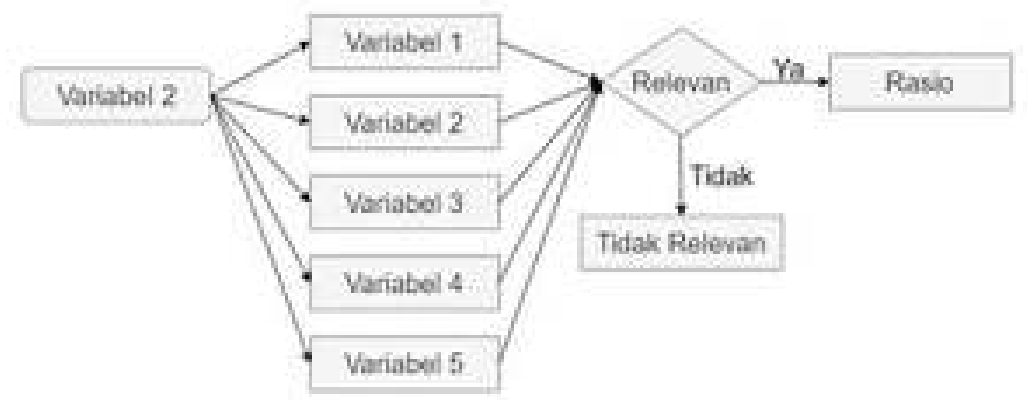

Gambar 3. Contoh Perbandingan Variabel Pada Akun YouTube

Pada gambar contoh perbandingan variabel pada akun YouTube, menunjukan bahwa variabel post dibandingkan atau disandingkan dengan keenam variabel yang lainnya. Hasil dari perbandingan antar variabel menunjukan bahwa variabel post yang dibandingkan dengan variabel post mendapatkan hasil yang tidak relevan. Sedangkan hasil perbandingan pada variabel post dengan variabel subscriber mendapatkan hasil yang relevan, sehingga dapat dijadikan sebuah rasio.

\section{HASIL DAN PEMBAHASAN}

Akun youtube 5 youtuber dengan subscriber terbanyak di indonesia, diantaranya :

\section{Atta Halilintar}

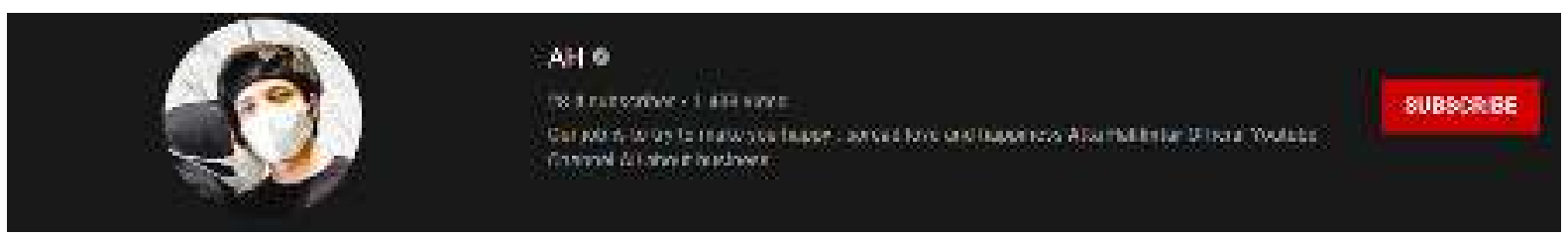

Gambar 4. Akun Youtube Atta Halilintar

Sumber : https://www.youtube.com/c/AttaHalilintar (akses pada 19-10-2021)

\section{Ria Ricis}

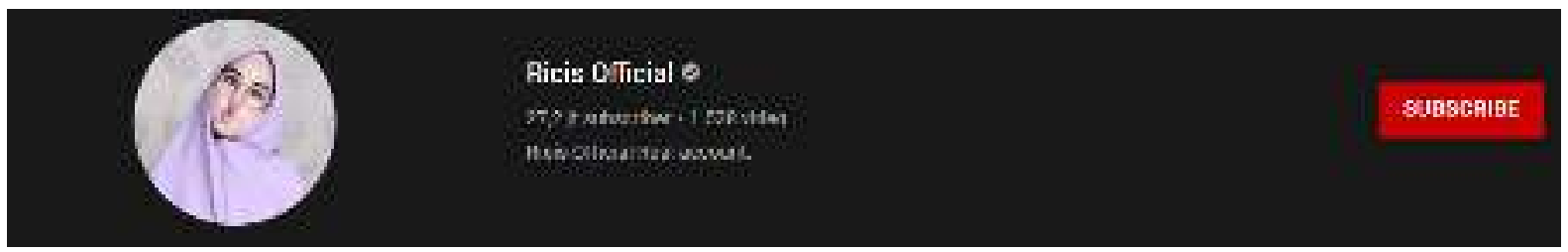

Gambar 5. Akun Youtube Ria Ricis

Sumber : https://www.youtube.com/c/Ricisofficial1795 (akses pada 19-10-2021) 


\section{Rans Entertaiment}

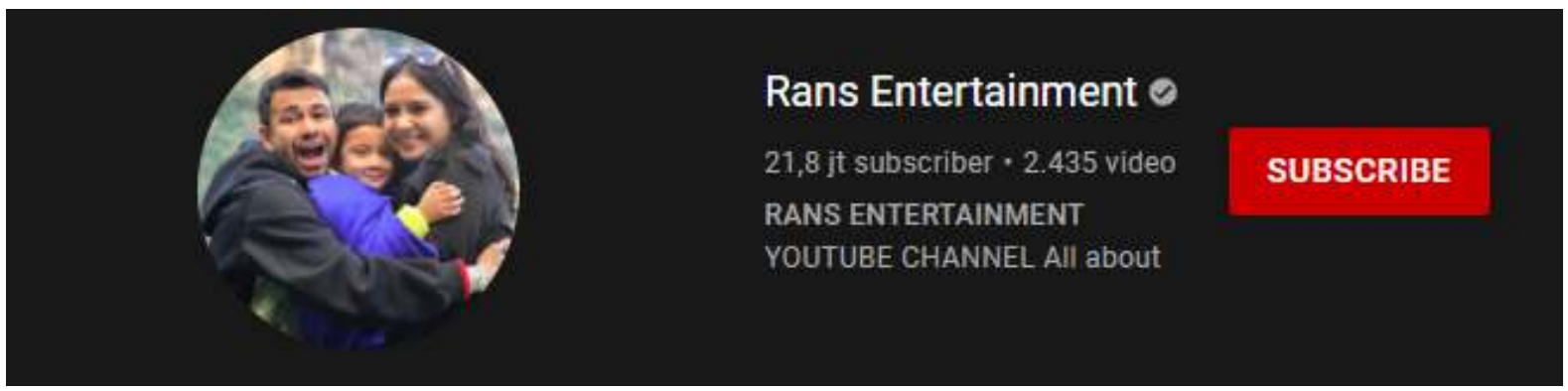

Gambar 6. Akun Youtube Rans Entertaiment

Sumber : https://www.youtube.com/c/RansEntertainment (akses pada 19-10-2021)

\section{Baim Paula}

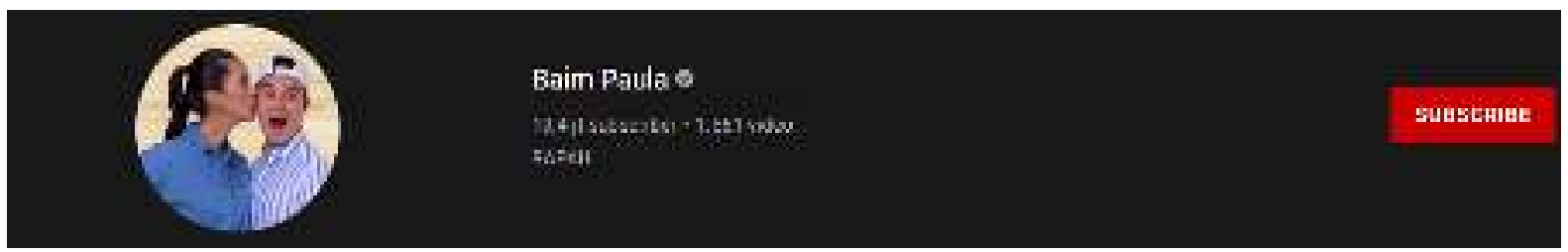

Gambar 7. Akun Youtube Baim Paula

Sumber : https://www.youtube.com/c/BaimPaula (akses pada 19-10-2021)

\section{Deddy Corbuzier}

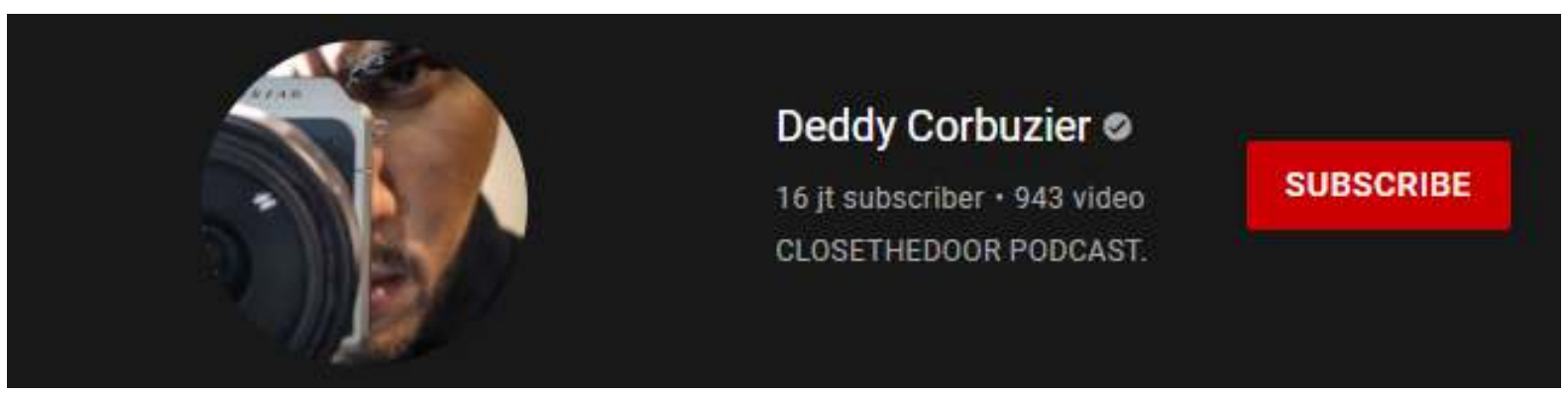

Gambar 8. Akun Youtube Deddy Corbuzier

Sumber : https://www.youtube.com/c/corbuzier (akses pada 19-10-2021)

Dari kelima akun 5 youtuber dengan subscriber terbanyak di indonesia peneliti menemukan nilai dari masing-masing variabel yang ada untuk menghitung rasio Post To Subscriber dari setiap akun. Pada akun Youtube terdapat 6 variabel, diantaranya yaitu :

1. Post

2. Subscriber

3. Likes

4. Dislikes

5. Comments

6. Viewers 
Dari keenam variabel tersebut peneliti hanya fokus untuk menemukan hasil dari 2 variabel, yaitu :

1. Post

2. Subscriber

Dari kedua variabel tersebut kemudian dianalisa sehingga menemukan nilai rata-rata dari variabel post dan variabel subscriber. Untuk menghitung nilai rata-rata dari variabel post dan subscriber yaitu dengan cara melihat 5 akun youtube kemudian di hitung sehingga menemukan nilai rata-rata dari masing-masing variabel. Berikut merupakan tabel nilai rata-rata dari masingmasing youtuber di Indonesia, yaitu :

Tabel 1. Analisa Nilai Rata-Rata Nilai Variabel Post dan Subscriber kelima Akun Youtube 5 Youtuber Indonesia

\begin{tabular}{|c|r|r|}
\hline Youtuber & \multicolumn{1}{|c|}{ Post } & Subscriber \\
\hline Atta Halilintar & 1400 & 27900000 \\
\hline Ria Ricis & 1500 & 27100000 \\
\hline $\begin{array}{c}\text { Rans } \\
\text { Entertaiment }\end{array}$ & 2400 & 21800000 \\
\hline Baim Paula & 1500 & 19500000 \\
\hline Deddy Corbuzier & 937 & 15900000 \\
\hline Total & $\mathbf{1 5 4 7 . 4}$ & $\mathbf{2 2 4 4 0 0 0 0}$ \\
\hline
\end{tabular}

Sumber : Pengolah Data Excel

Setelah menghitung nilai rata-rata tersebut, maka akan menemukan hasil akhir nilai rata-rata dari variabel post dan subscriber, yaitu:

Tabel 2. Nilai Variabel Pada Akun Youtube 5 Youtuber Subscriber Terbanyak di Indonesia

\begin{tabular}{|l|r|r|r|r|r|}
\hline Variabel & Atta Halilintar & Ria Ricis & \multicolumn{1}{c|}{$\begin{array}{c}\text { Rans } \\
\text { Entertaiment }\end{array}$} & \multicolumn{1}{c|}{ Baim Paula } & \multicolumn{1}{c|}{$\begin{array}{c}\text { Deddy } \\
\text { Corbuzier }\end{array}$} \\
\hline Post & 1400 & 1500 & 2400 & 1500 & 937 \\
\hline Subscriber & 27900000 & 27100000 & 21800000 & 19500000 & 15900000 \\
\hline
\end{tabular}

Pada penelitian kali ini berfokus untuk menghitung Post To Subscriber Ratio. Untuk menghitung kredibilitas dari masing-masing akun Youtube pada setiap youtuber, peneliti menghitung dengan cara : variabel 1 akan dibagi dengan variabel 2, sehingga ditemukan hasil analisisa dari rasio tersebut.

Tabel 3. Hasil Perhitungan Rasio Youtube

\begin{tabular}{|l|l|l|l|l|l|l|}
\hline NO & RATIO & $\begin{array}{l}\text { Atta } \\
\text { Halilintar }\end{array}$ & Ria Ricis & $\begin{array}{l}\text { Rans } \\
\text { Entertaiment }\end{array}$ & $\begin{array}{l}\text { Baim } \\
\text { Paula }\end{array}$ & $\begin{array}{l}\text { Deddy } \\
\text { Corbuzier }\end{array}$ \\
\hline
\end{tabular}


Post To Subscriber Ratio memiliki karakteristik yang tinggi, artinya semakin tinggi nilai yang dihasilkan maka semakin baik kredibilitas atu kualitas dari performa akun tersebut. Untuk memberikan peringkat pada masing-masing Youtuber, peneliti memberikan angka 5 kepada youtuber yang mendapatkan nilai tertinggi dan angka 1 untuk youtuber yang mendapatkan nilai terendah. Berikut merupakan tabel urutan nilai yang dihasilkan oleh masing-masing youtuber.

Tabel 8. Nilai Rasio Akun Youtube 5 Youtuber Subscriber Terbanyak Di Indonesia

\begin{tabular}{|l|c|c|l|l|l|}
\hline \multicolumn{2}{|c|}{ RATIO } & \multicolumn{5}{|c|}{ NILAI } \\
\cline { 2 - 6 } & $\begin{array}{l}\text { Atta } \\
\text { Halilintar }\end{array}$ & Ria Ricis & $\begin{array}{l}\text { Rans } \\
\text { Entertaiment }\end{array}$ & $\begin{array}{l}\text { Baim } \\
\text { Paula }\end{array}$ & $\begin{array}{l}\text { Deddy } \\
\text { Corbuzier }\end{array}$ \\
\hline $\begin{array}{l}\text { Post To Subscriber } \\
\text { Ratio }\end{array}$ & 1 & 2 & 5 & 4 & 3 \\
\hline
\end{tabular}

Sumber : Pengolah Data Excel

Dari Tabel Nilai Rasio Akun Youtube 5 youtuber subscriber terbanyak di Indonesia dapat simpulkan bahwa Atta Halilintar mendapatkan nilai tertinggi untuk rasio Post To Subscriber. Sedangkan akun Youtube Rans Entertaiment mendapatkan nilai terendah untuk rasio ini. Jadi, pada penelitian ini Atta Halilintar memiliki kredibilitas atau kualitas performa yang lebih baik dibandingkan dengan Youtuber yang lainnya.

\section{KESIMPULAN}

Tujuan dari penelitian ini adalah mengetahui kredibilitas atau kualitas performa dari akun Youtube 5 Youtuber Dengan Subscriber Terbanyak di Indonesia menggunakan Post To Subscriber Ratio. Berdasarkan karakteristik dan jumlah rasio dari kelima akun Youtuber tersebut dapat disimpulkan bahwa :

1. Peringkat pertama dengan nilai ratio 0.00005018 yaitu youtuber Atta Halilintar

2. Peringkat kedua dengan nilai ratio 0.00005535 yaitu youtuber Ria Ricis

3. Peringkat ketiga dengan nilai ratio 0.00005893 yaitu youtuber Deddy Corbuzier

4. Peringkat keempat dengan nilai ratio 0.00007692 yaitu youtuber Baim Paula

5. Peringkat kelima dengan nilai ratio 0.00011009 yaitu youtuber Rans Entertaiment 


\section{DAFTAR PUSTAKA}

Fadhal, Soraya, and Lestari Nurhajati. 2012. "Identifikasi Identitas Kaum Muda Di Tengah Media Digital (Studi Aktivitas Kaum Muda Indonesia Di Youtube)." Jurnal AL-AZHAR INDONESIA SERI PRANATA SOSIAL 1 (3): 176-200. http://jurnal.uai.ac.id/index.php/SPS/article/view/60.

Firman, Firman. 2018. "Penelitian Kualitatif Dan Kuantitatif," 1-29. https://doi.org/10.31227/osf.io/4nq5e.

Hadi S, Ika Brianti, Endang Pratiwi Kurniawan, and Irwansyah Irwansyah. 2021. "Pengungkapan Diri Di Situs Media Sosial Youtube." Jurnal Lensa Mutiara Komunikasi 5 (1): 42-51. https://doi.org/10.51544/jlmk.v5i1.1526.

Hendika Permana, I Putu. 2021. "Analisis Rasio Pada Akun Youtube Untuk Penelitian Kualitatif Menggunakan Metode Ekploratif.” Jurnal Ilmiah Media Sisfo 15 (1): 40. https://doi.org/10.33998/mediasisfo.2021.15.1.970.

"Ini-5-Youtuber-Dengan-Subscriber-Terbanyak-Raffi-Ahmad-Dan-Nagita-Slavina-Nomor-3K520qT." n.d.

Liana, Lie. 2009. "Penggunaan MRA Dengan Spss Untuk Menguji Pengaruh Variabel Moderating Terhadap Hubungan Antara Variabel Independen Dan Variabel Dependen." Jurnal Teknologi Informasi DINAMIK XIV (2): 90-97.

https://www.unisbank.ac.id/ojs/index.php/fti1/article/view/95/90.

"Pengertian Youtuber_Profesi, Gaji, Cara Kerja, Tips Viewers Dan Subscriber Tinggi Adam Muiz." n.d.

Sulaeman, A. R., Fazri, A., \& Fairus, F. 2020. "Strategi Pemanfaatan Youtube Dalam Bidang Dakwah Oleh Ulama Aceh." Communication 11 (1): 81-93. 